\title{
Positioning the T and E in STEM: A STL Analytical Content Review of Engineering and Technology Education Research
}

\author{
Paul A. Asunda \& Jenny Quintana
}

\begin{abstract}
Despite the presence of the Standards for Technological Literacy (STL) in engineering and technology curricula and in scholarly research (e.g., Strimel \& Grubbs, 2016; Kennedy, Quinn, \& Lyons, 2018; Bers, Seddighin, \& Sullivan, 2013; Harrison, 2011), it is now the Framework for K-12 Science Education (National Research Council, 2012) and the Next Generation Science Standards (NGSS Lead States, 2013) that are recognized and critiqued by organizations such as the American Society for Engineering Education. This study utilized an analytical content review of scholarly literature published during a recent 6-year period (2011-2016) to identify how engineering and technology researchers, including STEM professionals, position the T and E in the context of the STL in engineering and technology and STEM instruction. Findings revealed that the domains of Design, The Nature of Technology, and The Designed World of the STL provide a rich platform from which researchers and educators can employ evidence-based strategies to promote successful STEM learning.
\end{abstract}

Keywords: Engineering and technology education; STEM, STEM instruction; STL standards; the T and E of STEM

In the past 100 years, the subject known as engineering and technology education at the $\mathrm{K}-12$ level has gone through significant curricula changes. Since the passing of the Smith-Hughes National Vocational Education Act of 1917, the field has evolved from industrial arts to technology education and to its current name: engineering and technology education. The Jackson's Mill Industrial Arts Curriculum Theory introduced in 1981 by Snyder and Hales was the main benchmark for industrial arts teaching. This model revolved around " "four universal technical systems ... communication, construction, manufacturing, and transportation"' (Snyder \& Hales, 1981, p. 16; as cited in O'Riley, 1996, p. 30). In the early 90s, the International Technology Educators Association (ITEA), which was later renamed the International Technology and Engineering Educators Association (ITEEA), "updated the Jackson's Mill model, and also identified four universal content reservoirs (ITEA, 1990, p. 17): bio-related; communications; production; and, transportation" (O'Riley, 1996, p. 30). These areas were to be used to guide technology education instruction (O'Riley, 1996). Through these transitions, the meaning of engineering and 
technology as a school subject continues to be explored by the learning of theoretical concepts integrated with practical activities (de Vries, Custer, Dakers, \& Martin, 2007).

Today the learning of engineering and technology education as a subject is an important part of our school culture. The subject lays the foundation for building a vibrant STEM workforce through collaborative problem-solving experiences that lead to the creation of solutions to tomorrow's challenges. In recent years, curricula revisions in engineering and technology education and the development of standards - including the Standards for Technological Literacy (International Technology Education Association [ITEA], 2007), the Next Generation Science Standards (NGSS Lead States, 2013), and the Common Core State Standards - to match contemporary societal needs have been accompanied by educational research, detailing the rich products of the subject, best practices, and possible future research areas in scholarly technology and engineering education journals. As such, the study of technological processes continues to provide students with opportunities to learn about the processes of design, the fundamental concepts of technology and engineering, and the limits and possibilities of technology in society.

The Standards for Technological Literacy: Content for the Study of Technology (STL), national standards that were originally released by ITEA in 2000, identify and define 20 standards that "every student should know and be able to do in order to be technologically literate" (ITEA, 2007, p. 14). These standards are categorized into five key domains: (a) "The Nature of Technology," (b) "Technology and Society," (c) "Design," (d) “Abilities for a Technological World," and (e) "The Designed World" (ITEA, 2007, p. 14). The standards continuously guide teachers in the development of meaningful learning experiences that integrate engineering design practices for all students through STEM courses.

Despite the presence of the STL in engineering and technology curricula and in scholarly research since their inception in 2000 (e.g., Strimel \& Grubbs, 2016; Kennedy et al., 2018; Bers et al., 2013; Harrison, 2011), it is now the Framework for K-12 Science Education (National Research Council, 2012) and the Next Generation Science Standards (NGSS Lead States, 2013), which emphasize integration of engineering design into $\mathrm{K}-12$ science, that are recognized and critiqued by organizations such as the American Society for Engineering Education (Strimel \& Grubbs, 2016). "The ITEEA community or the Standards for Technological Literacy are only referenced minimally" (Strimel \& Grubbs, 2016, p. 22). This may indicate that there is little recognition of how engineering and technology educators deliver and position the $\mathrm{T}$ and $\mathrm{E}$ in STEM education and engineering and technology instructional practices. In this study, the term position is defined as how educators and professionals portray and situate the $\mathrm{T}$ and $\mathrm{E}$ in their teaching of STEM-related concepts. One way of demonstrating position of the $\mathrm{T}$ and $\mathrm{E}$ is through an analytical content review of 
scholarly literature from an STL perspective. This will enable articulation of how educators incorporate the standards into teaching, or how the $\mathrm{T}$ and $\mathrm{E}$ integrate with and promote the learning of STEM concepts. Analytical content reviews have been used successfully to identify research trends, best practices, and improve research in a variety of academic fields (Bryman, 2004; Titscher, Meyer, Wodak, \& Vetter, 2000).

To this end, we sought to identify how engineering and technology researchers, including STEM professionals, position the $\mathrm{T}$ and $\mathrm{E}$ in engineering and technology as a subject designed to educate students in the context of STEM instruction and initiatives. We examined the primary question: How are the Standards for Technological Literacy integrated into STEM instructional practices and research as reported in major STEM education professional journals from the years 2011-2016?

We acknowledge that STL might have received significant focus in professional journals and reports from the National Academies in the first decade since inception, which has tapered. Nevertheless, Hutchinson and Lovell (2004) observed that "professional journals serve an important function within most disciplines. They offer a mechanism by which professionals communicate ideas, stimulate discussion (as well as controversy), and share information, often in the form of research findings" (p. 383).

Given the key role peer-reviewed journals play in the development, promotion, and maintenance of a profession, periodic examinations of scholarly journals are a widely-reported practice across education and social science professions (Bangert \& Baumberger, 2005; Elmore \& Woehlke, 1998; Goodwin \& Goodwin, 1985; Rojewski, 1997). (Rojewski, Asunda, \& Kim, 2009, p. 57)

We also acknowledge that different learning environments may lead to different instructional practices. However, given this perspective, we anticipate that the findings of this analytical content review would accomplish two things. First, they would offer educators, researchers, practitioners, and policy makers immediate and emerging research needs toward the positioning of the $\mathrm{T}$ and $\mathrm{E}$ in teaching of engineering and technology education as an area to support STEM learning. Second, they would provide a rationale that will allow researchers and practitioners utilize STL and position particular instructional problems or projects that may support STEM learning within context of STL. As a result, this may equip educators with strategies to integrate STEM as they develop and connect STEM-rich learning environments. 


\section{Source of Literature}

The primary sources of literature for this review included all research articles published in three refereed scholarly journals: the Journal of Technology Education (JTE), the Journal of Engineering Education (JEE), and the Journal of STEM Education (JSTEM), during a recent 6-year period (2011-2016). These journals were purposefully selected for their focus on STEM initiatives and engineering and technology education. Articles published in these journals have a general, comprehensive scope in engineering and technology education, engineering education, and STEM education. These three journals are respected and possess a relatively high degree of prestige in the field. All three journals are sponsored by professional associations, are governed by an external board of reviewers, and use a blind review process.

\section{Method}

A research synthesis strategy (Cooper, 1998) was adopted. This strategy supported our efforts to examine primary or original scholarship on various aspects of how the $\mathrm{T}$ and $\mathrm{E}$ is being positioned in STEM education for the purpose of describing, integrating, and synthesizing contents of this scholarship from an STL perspective. We reviewed three peer-reviewed journals producing relevant studies in engineering and technology education scholarly work: the Journal of Technology Education (JTE), the Journal of Engineering Education (JEE), and the Journal of STEM Education (JSTEM). This processes yielded 361 original articles. The population did not include marginal, gray areas of the literature, such as unpublished reports, program evaluation reports, or other nonpeer-reviewed publications, because we were not interested in research practices reported in the entirety of engineering and technology education research. Rather, we were interested in research practices reported in current, peerreviewed, mainstream STEM-related research forums. We included full papers, but excluded poster summaries, demo summaries, editorials, conference reviews, book reviews, forewords, introductions, and prologues in the sampling frame. We then adopted and incorporated aspects of Neuendorf's $(2002,2009)$ Integrative Model of Content Analysis as a model for carrying out the review. Neuendorf (2002) describes content analysis as consisting of the following steps: (a) developing a theory and rationale, (b) conceptualizing variables, (c) operationalizing measures, (d) developing a coding form and coding book, (e) sampling, (f) training and determining pilot reliabilities, (g) coding, (h) calculating final reliabilities, and (i) analyzing and reporting data (pp. 50-51). We describe how we adopted these steps in the following section.

\section{Developing a Theory and Rationale}

We utilized the STL as a framework. The standards identify content necessary for $\mathrm{K}-12$ students, including knowledge, abilities, and capacities to apply both to the real world. The standards in the STL were built around a 
cognitive base as well as a doing or activity base. They include assessment criteria for specific grade levels (K-2, 3-5, 6-8, and 9-12). The STL articulate what needs to be taught in $\mathrm{K}-12$ laboratory classrooms to enable all students to develop technological literacy (ITEA, 2007). These standards are grounded in constructivist theory (see Tobin \& Tippins, 1993), which states that "knowledge is not passively received but actively built up by the cognizing subject," the learner (von Glasersfeld, 1989, p. 182).

\section{Conceptualizing Variables and Operationalizing Measures}

The STL standards are made up of five domains: The Nature of Technology (Standards 1-3), Technology and Society (Standards 4-7), Design (Standards810), Abilities for a Technological World (Standards 11-13), and The Designed World (Standards 14-20). The goal of these standards is to prepare students with a more conceptual understanding of technology and engineering and its place in society. As such, students are able to conceptualize and evaluate new technologies that they may have never before seen. By doing and making, children are able to become makers for the future.

Students who study technology learn about the technological world that inventors, engineers, and other innovators have created. They study how energy is generated from coal, natural gas, nuclear power, solar power, and wind, and how it is transmitted and distributed. They examine communication systems: telephone, radio and television, satellite communications, fiber optics, [and] the Internet. They delve into the various manufacturing and materials-processing industries, from steel and petrochemicals to computer chips and household appliances. They investigate transportation, information processing, and medical technology. They even look into new technologies, such as genetic engineering or emerging technologies, such as fusion power that is still years or decades away. (ITEA, 2007, p. 4)

\section{Developing a Coding Form and Coding Book}

To this end, we developed a coding sheet in Excel software, similar to the one described by Hutchinson and Lovell (2004), to guide our content analysis of each article included in the three journals to be selected for review. The coding sheet included the five categories and accompanying standards in an attempt to record how scholarly work was integrating the T and E in STEM. We searched for articles within the designated years (2011-2016) and built a database for ease of managing each journal, designated year, issues, volumes and number of articles. Two researchers in STEM education were invited to be interrater reliability reviewers. The STEM researchers had participated in previous analytical reviews in STEM studies and were invited to review the coding book over a period of 2 weeks and offer suggestions. After the 2 -week period, the first author read through the coding book and coding sheet together with the 
interrater reliability reviewers and discussed questions raised about the coding book or coding sheet. We then modified the noted inconsistencies in the coding book or coding sheet, and the two interrater reliability reviewers and the first author coded a purposive sample of 15 research articles (five articles per reviewer). These articles were not included in the final reliability subsample. We then asked the reviewers to independently code and position the $\mathrm{T}$ and $\mathrm{E}$ in the sample articles into STL standards and domains. The purposive sample consisted of STEM-related articles that the first author deemed representative of articles that incorporated elements of STL practices to be examined. The reviewers and the researchers also coded the articles. After both sets of coders had coded the articles, we came together to compare codes and discuss any noted inconsistencies. When any disagreements arose, we would try to determine the cause of the disagreement, and the first author would modify the coding book if it were cause of the disagreement. We then calculated the percent agreement for each domain, as suggested by Banerjee, Capozzoli, McSweeney, and Sinha (1999). Percent agreement reflects the number of times all three raters agreed upon an identified domain as present or absent divided by the total number of their agreements and disagreements, which is then multiplied by 100 . Since three raters analyzed the transcripts, the percent agreement expected by chance was $25 \%$. Therefore, agreement greater than $25 \%$ supported consistency among the raters. Percent agreements for each domain were: $82 \%$ for The Nature of Technology, 76\% for Technology and Society, 100\% for Design, 62\% for Abilities for a Technological World, and 90\% for The Designed World.

\section{Sampling}

Based on our search criteria, we narrowed the sample down to 361 original articles from the three peer-reviewed journals. These articles were analyzed for their content in order to identify evidence of how researchers position instances of technology and engineering practices in the context of the STL (ITEA, 2007) and its five domains in their work. We remodified the coding book and created a spreadsheet to help keep record of the page numbers, content, article title, authors' names, year, journal name, and the standards found during the examination.

\section{Analyzing and Reporting Data}

As an example, Table 1 illustrates a portion of the synthesis matrix that we developed to help organize excerpts from the articles in readiness for analysis of how the T and E was being incorporated in STEM through the STL standards (see appendices for full table). As such, each standard was a guide for classifying the articles' content into the five domains (i.e., The Nature of Technology, Technology and Society, Design, Abilities for a Technological World, and The Designed World). It is important to mention that some STL statements presented in the table do not only have evidence for exclusively one 
standard but have combinations of two or more. For example, the article by Reynolds, Yazdani, and Manzur (2013) included elements of design (i.e., Standard 8 and evidence of hands-on activities) and "structural components of a building, such as beams, columns, studs, and connections" (p. 14; i.e., Standard 20). Further, all evidence possible was collected from each article, whether the standard exhibited the positioning of the $\mathrm{T}$ and $\mathrm{E}$ or not. For example, Katsioloudis and Moye (2012) conducted a study "to determine the future critical issues and problems facing the K-12 technology and engineering education profession in the Commonwealth of Virginia" (p. 7), and in doing so, they underscored Standard 1 to support and justify their work.

\section{Findings}

In reference to the question guiding this study (How are the STL integrated into STEM instructional practices and research as reported in major STEM education professional journals from the years 2011-2016?), we examined 361 articles published in three peer reviewed journals: the Journal of Technology Education (JTE; six volumes, 13 issues, 59 articles), the Journal of Engineering Education (JEE; six volumes, 26 issues, 148 articles), and the Journal of STEM Education (JSTEM; seven volumes, 23 issues, 154 articles). We utilized the STL as a basis for understanding how the $\mathrm{T}$ and $\mathrm{E}$ had been positioned by researchers and scholars. We noted that in the three journals, nearly all of the 20 standards had been referenced in each journal, as presented in Table 2.

In JEE, Standards 8, 10, 3, 9, 4, 14, and 17 were referenced frequently, whereas Standards, 7, 12, and 18 were the least referenced. For example, Standard 8, "students will develop an understanding of the attributes of design" (ITEA, 2007, p. 91), is illustrated by Goncher and Johri (2015), who shared that constraints were a great tool to help develop student crtical thinking skills in various aspects of the design project. 


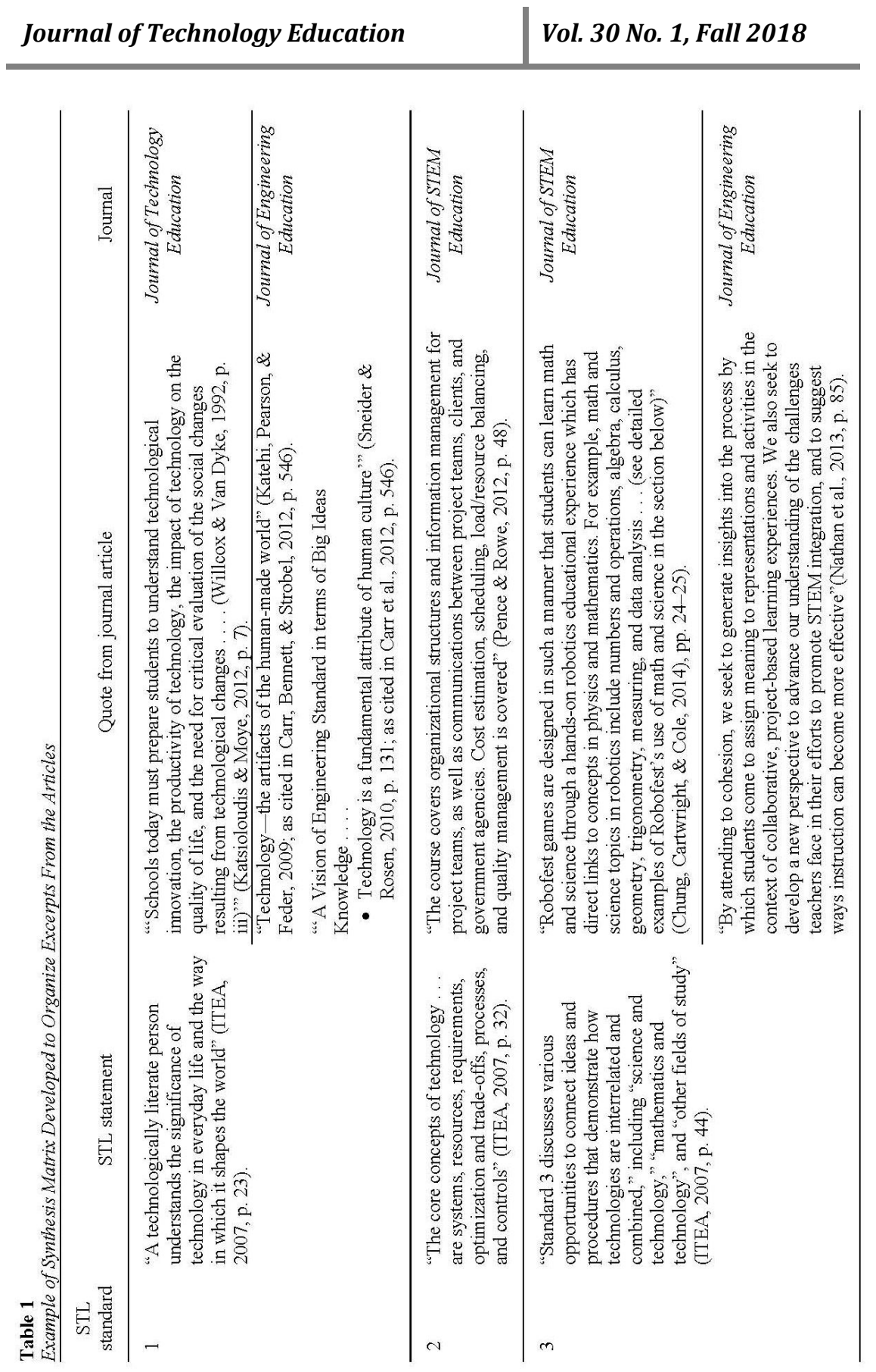

$-9-$ 
On the other hand, Nathan et al. (2013) demonstrated Standard 3 by noting that "by attending to cohesion [among aspects of the classroom related to learning], we seek to generate insights into the process by which students come to assign meaning to representations and activities in the context of collaborative, projectbased learning experiences" (p. 85).

Table 2

STL Standards as Referenced in JEE, JSTEM, and JTE

\begin{tabular}{ccccc}
\hline Standards & JEE & JSTEM & JTE & $\begin{array}{c}\text { Frequency across } \\
\text { journals }\end{array}$ \\
\hline 1 & 12 & 9 & 6 & 27 \\
2 & 7 & 8 & 3 & 18 \\
3 & 27 & 48 & 19 & 94 \\
4 & 19 & 17 & 6 & 42 \\
5 & 12 & 13 & 10 & 35 \\
6 & 4 & 4 & 4 & 12 \\
7 & 1 & 2 & 2 & 5 \\
8 & 37 & 25 & 18 & 80 \\
9 & 22 & 31 & 20 & 73 \\
10 & 37 & 42 & 10 & 89 \\
11 & 17 & 39 & 7 & 63 \\
12 & 1 & 10 & 4 & 15 \\
13 & 17 & 14 & 5 & 36 \\
14 & 2 & 7 & 4 & 13 \\
15 & 3 & 11 & 5 & 19 \\
16 & 8 & 9 & 2 & 19 \\
17 & 14 & 38 & 12 & 64 \\
18 & 1 & 4 & 2 & 7 \\
19 & 5 & 13 & 7 & 9 \\
20 & 0 & 6 & 3 & \\
\hline
\end{tabular}

As such, Nathan et al. (2013) and other researchers provide perspectives to advance our understanding of the challenges that teachers face in their efforts to promote the $\mathrm{T}$ and $\mathrm{E}$ in STEM integration and to suggest ways to make instruction more effective. Standard 4 was noted 19 times. According to Jamison, Kolmos, and Holgaard (2014), 
The perception of engineering that informs these approaches [in which engineering are combined with cultural context] is that of public service, or cultural appropriation, by which technologies are diffused or implemented into particular contexts of use (Jamison \& Hård, 2003). These approaches have grown out of social movements in the nineteenth and twentieth centuries that try to establish and provide a more socially relevant form of higher education, where engineering is not separated from the contextual and interdisciplinary nature of real-life problems. (p. 264)

The review also revealed that Standard 20, which calls for students to "develop an understanding of and be able to select and use construction technologies" (ITEA, 2007, p. 191), was not referenced in JEE. In JSTEM, Standards 3, 10, 11 , and 17 were frequently referenced, and the least noted standards were Standards 6, 7, and 18. Chung, Cartwright, and Cole (2014) illustrated Standard 3 by sharing that

Robofest games are designed in such a manner that students can learn math and science through a hands-on robotics educational experience which has direct links to concepts in physics and mathematics. For example, math and science topics in robotics include numbers and operations, algebra, calculus, geometry, trigonometry, measuring, and data analysis. (p. 24)

Standard 10 was noted 42 times. In reference to this standard, Ejiwale (2012) noted that

It is important that learning activities are open-ended, giving students the freedom to explore and experiment within their own interests and learning styles, rather than just encouraging recipes to right answers. The emphasis from the outset of student learning should be based on problem solving. (p. 91)

Standard 11 was noted 39 times, and Standard 17, "students will develop an understanding of and be able to select and use information and communication technologies" (ITEA, 2007, p. 166), was noted 38 times. The least noted standard was Standard 7, "Students will develop an understanding of the influence of technology on history" (ITEA, 2007, p. 79), which was noted two times. For example, White, Wood, and Jensen (2012) posited that

Although significant questions remain on what precise traits give a person the ability to be creative, there is general agreement that history has numerous examples of individuals who have exhibited tremendous creative accomplishments. The concept generation technique of "Historical Innovators" attempts to capture some of the principles that these 
extraordinary individuals used to accomplish their innovative feats and then apply these principles to the concept generation process. (p. 17)

Unlike JEE, in which Standard 20 was not noted, Standard 20 was noted six times in JSTEM. For example, as mentioned previously, Reynolds et al. (2013) illustrated "various structural components of a building such as beams, columns, studs, and connections" (p. 14). They also made teachers "aware of how faulty design and lack of quality control during construction could have severe detrimental effects during a wind event" (p. 14).

In JTE, Standards, 9, 3, and 8 were referenced frequently, and the least noted standards were Standards 7, 6, and 18. Standard 9 was noted 20 times. For example, Dixon and Johnson (2012) investigated "if there are differences in the cognitive process of engineering students and professional engineers as they use executive control processes (i.e., planning, monitoring, and evaluation) in the problem and solution spaces while solving an engineering design problem conceptually" (p. 77). Standard 3 was common across all three journals and was referenced 94 times. In other words, scholars envision a need to help students see the connection between different STEM fields. Standard 10, which was referenced 89 times, and Standard 8, which was referenced 80 times, both speak about the nature of design, and as such, the $\mathrm{T}$ and $\mathrm{E}$ is situated in Design practices. The least noted standards were Standards 7 and 18 . We further categorized the articles from major STEM education professional journals from the years 2011-2016 into the five STL domains and use this classification as a guide for reporting our findings in the following sections.

\section{Journal Analysis}

Table 3 presents findings from 2011 across the three journals. In 2011, out of 24 articles reviewed in JEE, the Design domain, which is made up of STL Standards, 8, 9, and 10, was noted 21 times. For example, researchers such as Adams et al. (2011); Capobianco, Diefes-Dux, Mena, and Weller (2011); Litzinger, Lattuca, Hadgraft, and Newstetter (2011); and Walther, Kellam, Sochacka, and Radcliffe (2011) envision design as a major element of engineering education curricula that transcends multiple fields. Embedding design as part of learning experiences of students promotes "creativity, ingenuity, communication, business, leadership, ethics, professionalism, dynamism, agility, resilience, flexibility, and lifelong learning ... (National Academy of Engineering, 2004)" (Borrego \& Bernhard, 2011, p. 18). 
Table 3

Year 2011: The Five STL Domains as Referenced in JEE, JSTEM, and JTE

\begin{tabular}{lcccccc}
\hline Journal & $\boldsymbol{n}$ & $\begin{array}{c}\text { The Nature } \\
\text { of } \\
\text { Technology }\end{array}$ & $\begin{array}{c}\text { Technology } \\
\text { and } \\
\text { Society }\end{array}$ & Design & $\begin{array}{c}\text { Abilities for a } \\
\text { Technological } \\
\text { World }\end{array}$ & $\begin{array}{c}\text { The } \\
\text { Designed } \\
\text { World }\end{array}$ \\
\hline JEE & 24 & 14 & 8 & 21 & 10 & 9 \\
JSTEM & 23 & 9 & 8 & 13 & 6 & 13 \\
JTE & 13 & 5 & 4 & 7 & 4 & 2 \\
\hline Total & 60 & 28 & 20 & 41 & 20 & 24 \\
\hline
\end{tabular}

Design is interwoven into the teaching of $\mathrm{T}$ and $\mathrm{E}$ concepts and was instrumental in devising solutions to problems. In this context, design is defined as the act of producing an item or product of need to society through a process that brings a concept from the drafting table or program into the real world (Bertola \& Texeira, 2003). The authors and researchers also noted that portfolio content reflections and design notebooks were learning interventions that foster knowledge integration in STEM environments to help connect concepts that showed design evidence. The domain Nature of Technology (i.e., STL Standards, 1, 2, and 3) was referenced 14 times. For instance, Charyton, Jagacinski, Merrill, Clifton, and DeDios (2011) noted that an interdisciplinary approach increased students' creativity and innovation. In other words, such an approach provided students' with an opportunity to see how each STEM discipline enhanced the other as a consequence of developing students' ingenuity and novelty in their thinking. The least noted domain was Technology and Society, which was referenced only eight times.

In the 23 articles that we reviewed in JSTEM, and the domains Design and The Designed World were depicted 13 times. The Designed World consists of STL Standards 14, 15, 16, 17, 18, 19, and 20. Foutz et al. (2011) "outline[d] a strategy which uses the discipline of agricultural engineering to integrate science and math both vertically and horizontally across the curriculum" and "to explore interdisciplinary approaches for understanding STEM concepts and to develop strategies to help students understand how these concepts are used to solve realword problems" (p. 25). Likewise, Connolly (2011) noted the use of engineering design process to inform product data management and product lifecycle management in an information systems course. The least noted domain was Abilities for a Technological World, which was noted six times.

For the 13 articles that we reviewed in JTE, Design as a domain was noted seven times. For example, Lee (2011) noted that "culture and design are always interwoven 'as design does not take place in isolation but is embedded in its user's culture' (Moalosi, Popovic, \& Hickling-Hudson, 2010, p. 1)” (p. 46). 
DeLuca and Lari (2011) reported that in the GRID c project, "students will learn how the disciplines of science and mathematics are used in the design and optimization of systems," and the project "will provide a platform for continued research and development of instructional materials that improve STEM education" (p. 15). Positioning of this standard provided students with an understanding of the influence of technology in contemporary society. The Nature of Technology was noted five times, and the least noted domain was The Designed World.

In summary, for publications in 2011, Design as a domain was noted 41 times in the three journals, followed by the Nature of Technology, which was noted 28 times. The main theme espoused in the Design domain in reference to the $\mathrm{T}$ and $\mathrm{E}$ was that design is fundamental in developing students' creativity and innovation toward addressing the needs of and solving problems in society.

\section{Journal Analysis}

Table 4 presents findings from 2012 across the three journals. In 2012, out of 30 articles reviewed in $J E E$, the Design domain was noted 15 times, 23 times in JSTEM, and 12 times in JTE.

In JEE, Finelli et al. (2012) articulated the importance of ethical development and practices in curricular experiences that supported design. In their review of "engineering in the K-12 STEM standards," Carr, Bennett, and Strobel (2012) pointed out that teaching the $\mathrm{T}$ and $\mathrm{E}$ incorporated within a design activity built around constraints is a value generative approach to solving problems or achieving goals. Crismond and Adams (2012) noted that "design experiences are also playing a more substantive role in precollege students' STEM ... education and career preparation" (p. 739). However, they noted that "advancements in the scholarship of design teaching and learning must therefore address two significant needs. First, the field lacks a coherent representation of design pedagogical content knowledge (Design PCK)" (p. 739), and "a second need for an integrative scholarship in engineering design is to help K-16 teachers access and interpret implications from design cognition research and render it usable for everyday classroom teaching" (p. 740). The Nature of Technology and Abilities for a Technological World were each referenced 10 times in $J E E$. 
Table 4

Year 2012: The Five STL Domains as Referenced in JEE, JSTEM, and JTE

\begin{tabular}{lcccccc}
\hline Journal & $\boldsymbol{n}$ & $\begin{array}{c}\text { The Nature } \\
\text { of } \\
\text { Technology }\end{array}$ & $\begin{array}{c}\text { Technology } \\
\text { and Society }\end{array}$ & Design & $\begin{array}{c}\text { Abilities for a } \\
\text { Technological } \\
\text { World }\end{array}$ & $\begin{array}{c}\text { The } \\
\text { Designed } \\
\text { World }\end{array}$ \\
\hline$J E E$ & 30 & 10 & 5 & 15 & 10 & 8 \\
$J S T E M$ & 35 & 16 & 9 & 23 & 16 & 18 \\
$J T E$ & 12 & 5 & 1 & 4 & 1 & 2 \\
\hline Total & 77 & 31 & 15 & 42 & 27 & 28 \\
\hline
\end{tabular}

We reviewed 35 articles in JSTEM, the domain Design was noted 23 times, compared to the previous year when it was noted only 13 times. Urias, Gallagher, and Wartman (2012) outlined that their Engineering Cities "REU experience is designed to encourage development of key skills that serve students throughout their careers" (p. 33); however, there was a need to have an assessment framework in evaluating efficacy of a given program that highlighted design practices as one of its instructional tenets. Similarly, Hagerty and Rockaway (2012) noted that the adaptation of "the entry level engineering course Statics ... to emphasize critical thinking skills, identify a culminating design experience, and promote alternative learnings styles .... had a positive effect on student performance" (p. 32). The domains The Nature of Technology and Abilities for a Technological World were each mentioned 16 times. For example, the $\mathrm{T}$ and $\mathrm{E}$ in The Nature of Technology (i.e., Standards 1, 2, and 3) were captured by Franchetti, Hefzy, Pourazady, and Smallman (2012) who noted that "design capstone projects for engineering students are essential components of an undergraduate program that enhances communication, teamwork and problem-solving skills" (p. 30). In the article, they present "a general framework that can be used by students and faculty to create a strong, industry-based senior design capstone course" (p. 30). Likewise, Pence and Rowe (2012) espoused the idea of adding engineering management courses (e.g., engineering economics, project management, and systems engineering) to engineering degree programs, as they have at Vanderbilt University, to better prepare students for their careers. "Students wishing to start new businesses required a plethora of skills including defining user requirements (Systems Engineering), building rapid prototypes (Project Management), defining stakeholder response (Technology Forecasting/Marketing), and funding/implementing a business plan (Technology-Based Entrepreneurship)" (p. 49). Abilities for a Technological World were demonstrated by Ejiwale (2012), who stated that "employers are looking for employees who possess the skills that are taught in STEM programs, including creative problem solving, 
product building, collaborative team work, design, and critical thinking (Aleman, 1992; Darling-Hammond, 1994)" (p. 87).

$J T E$ had 12 articles reviewed, and Design as a domain was noted only four times, a drop compared to the previous year. The least noted domains were Technology and Society and Abilities for a Technological World, which were each noted only once.

In summary, for 2012 publications, Design as a domain was noted 42 times in the three journals, followed by the Nature of Technology, which was noted 31 times. Again, the main themes positioning the $\mathrm{T}$ and $\mathrm{E}$ in STEM across the three journals in 2012 were from the Design domain. As such, design was viewed as an instructional strategy to build students' critical thinking skills and life long career abilities.

\section{Journal Analysis}

Table 5

Year 2013: The Five STL Domains as Referenced in JEE, JSTEM, and JTE

\begin{tabular}{lcccccc}
\hline $\begin{array}{c}\text { Journ } \\
\text { al }\end{array}$ & $\boldsymbol{n}$ & $\begin{array}{c}\text { The Nature } \\
\text { of } \\
\text { Technology }\end{array}$ & $\begin{array}{c}\text { Technology } \\
\text { and Society }\end{array}$ & Design & $\begin{array}{c}\text { Abilities for a } \\
\text { Technological } \\
\text { World }\end{array}$ & $\begin{array}{c}\text { The } \\
\text { Designed } \\
\text { World }\end{array}$ \\
\hline JEE & 27 & 6 & 4 & 12 & 4 & 9 \\
JSTEM & 25 & 9 & 4 & 9 & 7 & 7 \\
JTE & 12 & 4 & 4 & 5 & 2 & 6 \\
\hline Total & 64 & 19 & 12 & 26 & 13 & 22 \\
\hline
\end{tabular}

Table 5 presents findings from 2013 across the three journals. In 2013, the Design domain was noted 12 times, the Nature of Technology was noted six times, and Abilities for a Technological World was noted four times. In JSTEM, Design was noted nine times, and the Nature of Technology and Abilities for a Technological World were each referenced seven times. In JTE, Design as a domain was noted only five times. Out of 27 articles reviewed in JEE, for instance, Juhl and Lindegaard (2013) addressed the use of "visual representation to develop and integrate recognitions" (p. 20) and concluded that this enhanced engineering design practices. They argued that

Representations not only communicate findings but also incorporate analysis in their creation, and facilitate what we call collaborative design synthesis. Successful representations present and organize recognitions so that they are recognizable across other disciplines and can be integrated into new recognitions. Representations therefore shape the collaborative base of 
design process and emphasize important competencies that can produce them. (p. 20)

We reviewed 25 articles in JSTEM, and the domain Design was noted nine times. Reynolds et al. (2013) shared a teacher preparation workshop that enhanced STEM high school teachers' comprehension of the impact of manmade hazards (e.g., simulated effects of extreme wind loads on structures). In the lecture portion of the project,

a description of the various types of extreme winds and their effect on structures were shown through the use of mathematics and statistics. It was important for teachers to understand the mathematical and statistical processes involved in order to develop a lesson plan for their high school classes. (p. 12)

"Overall, the experience provided teachers with comprehensive knowledge, ranging from the nature of wind load to quantification on structures, and the method to evaluate the resulting response of structure" (p. 14). The Nature of Technology and Abilities for a Technological World were each mentioned seven times. Specifically, Hesser and Schwartz (2013) envisioned T and E positioned in both domains:

We envision the integration of iPads as a technology that will be introduced into many facets of learning .... allowing an increased level of student engagement. Using the iPads, students responded to questions asked by the instructor during class and answers were monitored interactively. (p. 8)

JTE had 12 articles reviewed, and Design as a domain was noted only five times. For example, Baskette and Fantz (2013) conducted a study "designed to gauge the ability of a single-semester course to raise students' technological literacy as well as gains in student perceptions of the importance of technology education in the K-12 curriculum" (p. 3). They suggested that "understanding what technology is, and is not, is the first step in becoming technologically literate" (p. 2). "Efforts should be made to include content that emphasizes the global impact of technological literacy and the need to understand how it was developed, how it works, and how it shapes society and individuals" (p. 18). The least noted domain was Abilities for a Technological World, which was depicted only twice.

In summary, for 2013 publications, Design as a domain was noted 26 times across the three journals. The main theme situating the $\mathrm{T}$ and $\mathrm{E}$ in the Design domain was the use of simulated visuals and representations to enhance students' comprehension and level of engagement in learning key design competencies. 


\section{Journal Analysis}

Table 6 presents findings from 2014 across the three journals. In 2014, out of 24 articles reviewed in JEE, the Design domain was noted four times; this was the least referenced time throughout the review. For example, Klotz et al. (2014) posited that sustainability was "a route to broadening participation in engineering." Klotz et al. (2014), specifically mentioned that "many of NAE's Grand Challenges (NAE, 2012) for engineering do align with the outcome expectations of those students we would like to be attracting" (p. 149). "Opportunities abound to emphasize the human impact of engineering through sustainability issues" (p. 149).

Table 6

Year 2014: The Five STL Domains as Referenced in JEE, JSTEM, and JTE

\begin{tabular}{lcccccc}
\hline Journal & $\boldsymbol{n}$ & $\begin{array}{c}\text { The Nature } \\
\text { of } \\
\text { Technology }\end{array}$ & $\begin{array}{c}\text { Technology } \\
\text { and Society }\end{array}$ & Design & $\begin{array}{c}\text { Abilities for a } \\
\text { Technological } \\
\text { World }\end{array}$ & $\begin{array}{c}\text { The } \\
\text { Designed } \\
\text { World }\end{array}$ \\
\hline JEE & 24 & 2 & 4 & 4 & 1 & 3 \\
JSTEM & 16 & 9 & 2 & 8 & 4 & 3 \\
JTE & 11 & 3 & 1 & 4 & 1 & 6 \\
\hline Total & 51 & 14 & 7 & 16 & 6 & 12 \\
\hline
\end{tabular}

Likewise, the domain Technology and Society was depicted four times, and the least referenced was Abilities for a Technological World, which was referenced only once. In JSTEM, the Nature of Technology domain was noted nine times. For instance, Kapila and Iskander (2014) posited that

As technology continues to profoundly impact our daily lives, it is essential that all students receive comprehensive, high quality education in STEM subjects because K-12 students must achieve high scores on standardized STEM courses to advance in society. Unfortunately, many science labs often make use of antiquated technology that fails to tap the potential of modern technology in order to create and deliver exciting lab content. As a result, students are turned off by science, fail to excel on standardized science exams and do not consider STEM as a career option. Integrating modern sensing technology into science labs presents one answer to the declining interest in STEM disciplines among American high school students. (pp. 49-50) 
This was the first time in the review that the Nature of Technology domain had outpaced Design in the review across the three journals. Design was noted eight times.

JTE had 11 articles reviewed, and Design as a domain was noted four times. For example, in his article "A Curricular Analysis of Undergraduate Technology \& Engineering Teacher Preparation Programs in the United States," Litowitz (2014) noted that design, including product design, innovation, problem solving, industrial design, and engineering design, was a frequently required technical course (pp. 76-77). The least noted domains were Abilities for a Technological World and Technology and Society, which were each depicted only once.

In summary, for 2014 publications, Design as domain was noted 16 times in the three journals, followed by the Nature of Technology, which was noted 14 times. However, researchers' depicted infusion of T and E concepts into the Nature of Technology as a vehicle in enhancing the learning of STEM concepts, especially in preparing students considering STEM careers.

\section{Journal Analysis}

Table 7

Year 2015: The Five STL Domains as Referenced in JEE, JSTEM, and JTE

\begin{tabular}{lcccccc}
\hline Journal & $\boldsymbol{n}$ & $\begin{array}{c}\text { The Nature } \\
\text { of } \\
\text { Technology }\end{array}$ & $\begin{array}{c}\text { Technology } \\
\text { and Society }\end{array}$ & Design & $\begin{array}{c}\text { Abilities for a } \\
\text { Technological } \\
\text { World }\end{array}$ & $\begin{array}{c}\text { The } \\
\text { Designed } \\
\text { World }\end{array}$ \\
\hline JEE & 20 & 6 & 4 & 10 & 4 & 2 \\
$J S T E M$ & 26 & 6 & 5 & 12 & 13 & 13 \\
JTE & 9 & 3 & 3 & 6 & 4 & 4 \\
\hline Total & 55 & 15 & 12 & 28 & 21 & 19 \\
\hline
\end{tabular}

Table 7 presents findings from 2015 across the three journals. In 2015, out of 20 articles reviewed in JEE, the Design domain was noted 10 times, the Nature of Technology was depicted six times, and the least noted was The Designed World, which was mentioned two times. With regard to the Design domain, Gilbuena et al. (2015) examined design coaching and feedback as a way to help students participating "in engineering design projects ... to practice both professional and technical skills. Feedback on professional skills helps students recognize how to simultaneously represent themselves as legitimate members of multiple communities of practice" (p. 7). Additionally, Atadero, Rambo-

Hernandez, and Balgopal (2015) examined how participation in group design projects affects "student content knowledge and intentions to persist in engineering" and noted that "there were strong positive relationships between 
self-efficacy and outcome expectations and between intention to persist and content knowledge" promoting students' "own abilities, goals, and success in engineering" and technology related subjects (p. 55).

In JSTEM, the Abilities for a Technological World domain (Standards, 11, 12, and 13) was referenced 13 times. This was the first time in the review that the domain had been ranked highly in the three journals reviewed. For example, Bowen and DeLuca (2015) examined the use of simulation and modeling in technology and engineering education classrooms and how these affected student content knowledge learning, performance, and engagement. They concluded that

additional research needs to be conducted .... Specifically, the balance of the value of content knowledge and performance must be determined for effective curriculum development, and how the learning outcomes of the project are aligned with state standards, national standards, and standards for technological literacy. (p. 9)

Design was noted 12 times. For example, Huang, Mejia, Becker, and Neilson (2015) stated:

This article investigates physics learning and teaching research and the use of engineering design in the teaching of physics. By integrating engineering into STEM, students may apply scientific ideas to solving an engineering design problem while carrying and transferring knowledge in core science areas. (p. 31)

This conclusion by Huang et al. also positioned the $\mathrm{T}$ and $\mathrm{E}$ in the Nature of Technology domain (Standard 3) as well.

$J T E$ had nine articles reviewed, and Design as a domain was noted six times. For example, in their article "Identifying Characteristics of Technology and Engineering Teachers Striving for Excellence Using a Modified Delphi," Rose, Shumway, Carter, and Brown (2015) found that one of the characteristics deemed most important in such an instructor is one who "inspires students' curiosity, creativity, ingenuity, and innovative spirit" (p. 11). Although it was not found to be critically important, an instructor also "knows and is able to apply an engineering design process to design a potential solution" (p. 13).

In summary, for 2015 publications, the Abilities for a Technological and The Designed World domains were ranked highly. In essence, these domains situated the T and E in STEM by promoting effective curricula that enhanced student content knowledge learning, performance, and engagement. 


\section{Journal Analysis}

Table 8 presents findings from 2016 across the three journals. In 2016, out of 21 articles reviewed in JEE, the Design domain was noted seven times. For example, Litchfield, Javernick-Will, and Maul (2016) noted that "engineers must acquire increasing technical and professional skills to meet pressing global challenges" through participation in engineering service projects (p. 70).

Table 8

Year 2016: The Five STL Domains as Referenced in JEE, JSTEM, and JTE

\begin{tabular}{lcccccc}
\hline Journal & $\boldsymbol{n}$ & $\begin{array}{c}\text { The Nature } \\
\text { of } \\
\text { Technology }\end{array}$ & $\begin{array}{c}\text { Technology } \\
\text { and Society }\end{array}$ & Design & $\begin{array}{c}\text { Abilities for a } \\
\text { Technological } \\
\text { World }\end{array}$ & $\begin{array}{c}\text { The } \\
\text { Designed } \\
\text { World }\end{array}$ \\
\hline JEE & 21 & 3 & 4 & 7 & 1 & 2 \\
JSTEM & 30 & 6 & 5 & 25 & 5 & 10 \\
JTE & 5 & 3 & 1 & 5 & 2 & 3 \\
\hline Total & 56 & 12 & 10 & 37 & 8 & 15 \\
\hline
\end{tabular}

In JSTEM, the Design domain was noted 25 times. For instance, in the program described by Franchetti and Ariss (2016), "design projects involved the creation of cross-disciplinary design teams comprised of engineering students, business students, engineering faculty, business faculty, entrepreneurs, and professional engineers" (p. 29). "Collaborative and Project-Based Learning (PBL) have been shown to increase individual learning through co-construction and personal reflection [Brindley et al., 2009]" (p. 29).

In JTE, five articles were examined, and Design as a domain was noted five times. Wilhelmsen and Dixon (2016) investigated "engineering design constructs identified by Childress and Rhodes (2008)" and concluded that "more questions still need to be answered. For example, can an instrument be developed from the indicators that validly and reliably assesses students' outcomes in design? What indicators should be included on such an instrument?" (p. 75).

In summary, for 2016 publications, the $\mathrm{T}$ and $\mathrm{E}$ would greatly be enhanced in STEM subjects through engineering service projects that incorporated crossdisciplinary teams. Nevertheless, a much needed area of research noted was "assessment of the outcomes" of the design process. 


\section{1-2016 Journal Analysis}

Table 9

Year 2011-2016: The Five STL Domains as Referenced in JEE, JSTEM, and JTE

\begin{tabular}{cccccc}
\hline Year & $\begin{array}{c}\text { The Nature } \\
\text { of } \\
\text { Technology }\end{array}$ & $\begin{array}{c}\text { Technology } \\
\text { and Society }\end{array}$ & Design & $\begin{array}{c}\text { Abilities for a } \\
\text { Technological } \\
\text { World }\end{array}$ & $\begin{array}{c}\text { The } \\
\text { Designed } \\
\text { World }\end{array}$ \\
\hline 2011 & 28 & 20 & 41 & 20 & 24 \\
2012 & 31 & 15 & 42 & 27 & 28 \\
2013 & 19 & 12 & 26 & 13 & 22 \\
2014 & 14 & 7 & 16 & 6 & 12 \\
2015 & 15 & 12 & 28 & 21 & 19 \\
2016 & 12 & 10 & 37 & 8 & 15 \\
\hline Total & 119 & 76 & 190 & 95 & 120 \\
\hline
\end{tabular}

Table 9, provides a summary of the five domains, as referenced in the 6year review across the three journals. Researchers and scholars in the field position the $\mathrm{T}$ and $\mathrm{E}$ in Design, and they cumulatively referenced the Design domain 190 times. Specifically, as evidenced in Table 2, Standards 8, 9, and 10 were referenced 242 times in total. The Designed World follows at a distant second, having been referenced 120 times. Standards 14, 15, 16, 17, 18, 19, and 20 in this domain were referenced 156 times in total (see Table 2). The Nature of Technology was referenced 119 times, and Standards 1, 2, and 3 were referenced 139 times in total (see Table 2).

Implications for Situating the $\mathrm{T}$ and $\mathrm{E}$ through STL

These findings suggest that the T and E situated in the STL standards, specifically the domains Design, The Nature of Technology, and The Designed World in STEM coursework and engineering and technology education, provide a rich platform from which researchers and educators can employ evidencebased strategies to promote successful learning. Researchers and educators designate the Design domain by situating the T and E in STEM through projects and problems situated in a design context to introduce STEM-related content. In other words, engineering and technological design practices are accentuated through active learning strategies that seek to develop students' ingenuity and novelty that purposefully enhances their understanding of STEM concepts. Compton and Harwood (2005) describe technology as "purposeful intervention by design" through engineering practices. It's through these technological 
practices that the rich products of the designed worlds are then engineered and have impact on our lives. The findings of this study, specifically examples noted from the domains of The Nature of Technology, Design, and The Designed World, continue to support the notion that technological outcomes are engineered to enhance the capabilities of people and expand human possibilities. The Nature of Technology domain is interwoven in STEM disciplines and engineering and technology curricula, providing educators with opportunities to develop learning episodes through strategies such as linked curricula, common language and subject matter, shared teaching and learning approaches, and joint activities to enhance the learning of STEM concepts. Likewise, in order to develop an understanding of the domain The Designed World, by selecting and utilizing appropriate, medical technologies, agricultural and related biotechnologies, information and communication technologies, transportation technologies, manufacturing technologies, and construction technologies, students need to develop an understanding of the attributes of design, engineering design, the role of troubleshooting, research and development, invention and innovation, and experimentation in problem solving. Therefore, the findings of this study imply that the $\mathrm{T}$ and $\mathrm{E}$ in the domains Design and The Designed World offer students and educators alike integrated STEM experiences that perpetuate The Nature of Technology. It then may be argued that positioning of the T and E through STL continues to enhance students' and educators' abilities in relation to the technology and engineering practices that they use to understand society and historical practices that have shaped cultural, social, economic, and political effects of technology across formal and informal settings. Such experiences may help students build complex skills such as leadership, collaboration, critical thinking, communication, creativity, and the ability to solve problems using mathematical, scientific, engineering, and technological practices.

\section{Wicklein (2006) suggested that}

The benefits of an engineering-design-focused curriculum for technology education are huge. If done correctly, technology education as a subject will be viewed and understood in an entirely different light. Students and parents will see a curriculum that is organized and systematic, leading to valued career options. School administrators and counselors will have a curriculum that provides multiple options for students, both college-bound and noncollege-bound. Engineering educators will receive a more prepared student who understands engineering design processes from the beginning of his/her college experience. Business and industry will have more U.S. citizens entering the STEM workforce. This is a viable future for technology education; are we willing to take the challenge? (p. 29) 
Findings suggest that the STL domains provide students with a vehicle to comprehend how technology integrates with engineering practices in the curricular. This analytical review has highlighted varied scholarly examples that support problem-based, hands-on learning opportunities. Positioning of the T and E in STEM-related courses and engineering and technology education affects the field as a whole. How are you positioning the T and E in your STEM instruction?

\section{References}

Adams, R., Evangelou, D., English, L., de Figueiredo, A. D., Mousoulides, N., Pawley, A. L., . . W Wilson, D. M. (2011). Multiple perspectives on engaging future engineers. Journal of Engineering Education, 100(1), 48-88. doi:10.1002/j.2168-9830.2011.tb00004.x

Atadero, R. A., Rambo-Hernandez, K. E., \& Balgopal, M. M. (2015). Using social cognitive career theory to assess student outcomes of group design projects in statics. Journal of Engineering Education, 104(1), 55-73. doi: $10.1002 /$ jee. 20063

Banerjee, M., Capozzoli, M., McSweeney, L., \& Sinha, D. (1999). Beyond kappa: A review of interrater agreement measures. The Canadian Journal of Statistics, 27(1), 3-23. doi:10.2307/3315487

Baskette, K. G., \& Fantz, T. D. (2013). Technological literacy for all: A course designed to raise the technological literacy of college students. Journal of Technology Education, 25(1), 2-19. doi:10.21061/jte.v25i1.a.1

Bers, M. U., Seddighin, S., \& Sullivan, A. (2013). Ready for robotics: Bringing together the T and E of STEM in early childhood teacher education. Journal of Technology and Teacher Education, 21(3), 355-377.

Bertola, P., \& Texeira, J. C. (2003). Design as a knowledge agent. How design as a knowledge process is embedded into organizations to foster innovation. Design Studies, 24(2), 181-194. doi:10.1016/S0142-694X(02)00036-4

Borrego, M., \& Bernhard, J. (2011). The emergence of engineering education research as an internationally connected field of inquiry. Journal of Engineering Education, 100(1), 14-47. doi:10.1002/j.21689830.2011.tb00003.x

Bowen, B., \& Deluca, W. (2015). Comparing traditional versus alternative sequencing of instruction when using simulation modeling. Journal of STEM Education, 16(1), 5-10. Retrieved from https://jstem.org/index.php/JSTEM/article/view/1896

Bryman, A. (2004). Social research methods (2nd ed.). New York, NY: Oxford University Press.

Capobianco, B. M., Diefes-Dux, H. A., Mena, I., \& Weller, J. (2011). What is an engineer? Implications of elementary school student conceptions for 
engineering education. Journal of Engineering Education, 100(2), 304-328. doi:10.1002/j.2168-9830.2011.tb00015.x

Carr, R. L., Bennett, L. D., IV, \& Strobel, J. (2012). Engineering in the K-12 STEM standards of the 50 U.S. states: An analysis of presence and extent. Journal of Engineering Education, 101(3), 539-564. doi:10.1002/j.21689830.2012.tb00061.x

Charyton, C., Jagacinski, R. J., Merrill, J. A., Clifton, W., \& DeDios, S. (2011). Assessing creativity specific to engineering with the revised Creative Engineering Design Assessment. Journal of Engineering Education, 100(4), 778-799. doi:10.1002/j.2168-9830.2011.tb00036.x

Chung, C., Cartwright, C., \& Cole, M. (2014). Assessing the impact of an autonomous robotics competition for STEM education. Journal of STEM Education, 5(2), 24-34. Retrieved from http://www.jstem.org/index.php/JSTEM/article/view/1704

Compton, V., \& Harwood, C. (2005). Progression in technology education in New Zealand: Components of practice as a way forward. International Journal of Technology and Design Education, 15(3), 253-287. doi:10.1007/s10798-004-5401-6

Connolly, P. E. (2011).The application of an engineering design and information systems case study in a senior level product data management course. Journal of STEM Education, 12(3-4), 35-45. Retrieved from https://jstem.org/index.php/JSTEM/article/view/1489

Cooper, H. (1998). Synthesizing research: A guide for literature reviews (3rd ed.). Thousand Oaks, CA: Sage.

Crismond, D. P., \& Adams, R. S. (2012). The Informed Design Teaching and Learning Matrix. Journal of Engineering Education, 101(4), 738-797. doi:10.1002/j.2168-9830.2012.tb01127.x

DeLuca, V. W., \& Lari, N. (2011). The GRID Project: Developing students' thinking skills in a data-rich environment. Journal of Technology Education, 23(1), 5-18. doi:10.21061/jte.v23i1.a.2

de Vries, M., Custer, R., Dakers, J., \& Martin, G. (Eds.). (2007). Analyzing best practices in technology education. Rotterdam, the Netherlands: Sense.

Dixon, R. A., \& Johnson, S. D. (2012). The use of executive control processes in engineering design by engineering students and professional engineers. Journal of Technology Education, 24(1), 73-89. doi:10.21061/jte.v24i1.a.5

Ejiwale, J. A. (2012). Facilitating teaching and learning across STEM fields. Journal of STEM Education, 13(3), 87-94. Retrieved from https://jstem.org/index.php/JSTEM/article/view/1711

Finelli, C. J., Holsapple, M. A., Ra, E., Bielby, R. M., Burt, B. A., Carpenter, D. D., ... Sutkus, J. A. (2012). An assessment of engineering students' curricular and co-curricular experiences and their ethical development. Journal of Engineering Education, 101(3), 469-494. doi:10.1002/j.21689830.2012.tb00058.x 
Foutz, T., Navarro, M., Hill, R. B., Thompson, S. A., Miller, K., \& Riddleberger, D. (2011). Using the discipline of agricultural engineering to integrate math and science. Journal of STEM Education, 12(1-2), 24-32. Retrieved from https://jstem.org/index.php/JSTEM/article/view/1577

Franchetti, M., \& Ariss, S. A. (2016). The implementation of senior design capstone projects combining engineering and business students. Journal of STEM Education, 17(4), 29-34. Retrieved from https://jstem.org/index.php/JSTEM/article/view/2163

Franchetti, M., Hefzy, M. S., Pourazady, M., \& Smallman, C. (2012). Framework for implementing engineering senior design capstone courses and design clinics. Journal of STEM Education, 13(3), 30-45. Retrieved from https://jstem.org/index.php/JSTEM/article/view/1561

Gilbuena, D. M., Sherrett, B. U., Gummer, E. S., Champagne, A. B., \& Koretsky, M. D. (2015). Feedback on professional skills as enculturation into communities of practice. Journal of Enginerring Education, 104(1), 734. doi:10.1002/jee.20061

Goncher, A., \& Johri, A. (2015). Contextual constraining of student design practices. Journal of Engineering Education, 104(3), 252-278. doi: $10.1002 /$ jee. 20079

Hagerty, D. J., \& Rockaway, T. D. (2012). Adapting entry-level engineering courses to emphasize critical thinking. Journal of STEM Education, 13(2), 25-34. Retrieved from https://jstem.org/index.php/JSTEM/article/view/1547

Harrison, M. (2011). Supporting the T and the E in STEM : 2004-2010. Design and Technology Education: An International Journal, 16(1), 17-25. Retrieved from https://ojs.lboro.ac.uk/DATE/article/view/1591

Hesser, T. L., \& Schwartz, P. M. (2013). iPads in the science laboratory: Experience in designing and implementing a paperless chemistry laboratory course. Journal of STEM Education, 14(2), 5-9. Retrieved from https://jstem.org/index.php/JSTEM/article/view/1827

Huang, S., Mejia, J. A., Becker, K., \& Neilson, D. (2015). High school physics: An interactive instructional approach that meets the Next Generation Science Standards. Journal of STEM Education, 16(1), 31-40. Retrieved from https://jstem.org/index.php/JSTEM/article/view/1813

Hutchinson, S. R., \& Lovell, C. D. (2004). A review of methodological characteristics of research published in key journals in higher education: Implications for graduate research training. Research in Higher Education, 45(4), 383-403. doi:10.1023/B:RIHE.0000027392.94172.d2

International Technology Education Association. (2007). Standards for technological literacy: Content for the study of technology (3rd ed.). Reston, VA: Author. 
Jamison, A., Kolmos, A., \& Holgaard, J. E. (2014). Hybrid learning: An integrative approach to engineering education. Journal of Engineering Education, 103(2), 253-273. doi:10.1002/jee.20041

Juhl, J., \& Lindegaard, H. (2013). Representations and visual synthesis in engineering design. Journal of Engineering Education, 102(1), 20-50. doi: $10.1002 /$ jee. 20001

Kapila, V., \& Iskander, M. (2014). Lessons learned from conducting a K-12 project to revitalize achievement by using instrumentation in science education. Journal of STEM Education, 15(1), 46-51. Retrieved from https://jstem.org/index.php/JSTEM/article/view/1760

Katsioloudis, P., \& Moye, J. J. (2012). Future critical issues and problems facing technology and engineering education in the Commonwealth of Virginia. Journal of Technology Education, 23(2), 6-24. doi:10.21061/jte.v23i2.a.1

Kennedy, J., Quinn, F., \& Lyons, T. (2018). Australian enrolment trends in technology and engineering: putting the T and $\mathrm{E}$ back into school STEM. International Journal of Technology and Design Education, 28(2), 553571. doi:10.1007/s10798-016-9394-8

Klotz, L., Potvin, G., Godwin, A., Cribbs J., Hazari, Z., \& Barclay, N. (2014). Sustainability as a route to broadening participation in engineering. Journal of Engineering Education, 103(1), 137-153. doi:10.1002/jee.20034

Lee, K. (2011). Looking back, to look forward: Using traditional cultural examples to explain contemporary ideas in technology education. Journal of Technology Education, 22(2), 42-52. doi:10.21061/jte.v22i2.a.3

Litchfield, K., Javernick-Will, A., \& Maul, A. (2016). Technical and professional skills of engineers involved and not involved in engineering service. Journal of Engineering Education, 105(1), 70-92. doi:10.1002/jee.20109

Litowitz, L. S. (2014). A curricular analysis of undergraduate technology \& engineering teacher preparation programs in the United States. Journal of Technology Education, 25(2), 73-84. doi:10.21061/jte.v25i2.a.5

Litzinger, T. A., Lattuca, L. R., Hadgraft, R. G., \& Newstetter, W. C. (2011). Engineering education and the development of expertise. Journal of Engineering Education, 100(1), 123-150. doi:10.1002/j.21689830.2011.tb00006.x

Nathan, M. J., Srisurichan, R., Walkington, C., Wolfgram, M., Williams, C., \& Alibali, M. W. (2013). Building cohesion across representations: A mechanism for STEM integration. Journal of Engineering Education, 102(1), 77-116. doi:10.1002/jee.20000

National Research Council. (2012). A framework for K-12 science education: Practices, crosscutting concepts, and core ideas. Washington, DC: National Academies Press. doi:10.17226/13165

Neuendorf, K. A, (2002). The content analysis guidebook. Thousand Oaks, CA: Sage. 
Neuendorf, K. A. (2009). Reliability for content analysis. In A. B. Jordan, D. Kunkel, J. Manganello, \& M. Fishbein (Eds.), Media messages and public health: A decisions approach to content analysis (pp. 67-87). New York, NY: Routledge.

NGSS Lead States. (2013). Next generation science standards: For states, by states. Washington, DC: National Academies Press. doi:10.17226/18290

O'Riley, P. (1996). A different storytelling of technology education curriculum re-visions: A storytelling of difference. Journal of Technology Education, 7(2), 28-40. doi:10.21061/jte.v7i2.a.3

Pence, K. R., \& Rowe, C. J. (2012). Enhancing engineering education through engineering management. Journal of STEM Education, 13(3), 46-51. Retrieved from https://jstem.org/index.php/JSTEM/article/view/1661

Reynolds, D., Yazdani, N., \& Manzur, T. (2013). STEM high school teaching enhancement through collaborative engineering research on extreme winds. Journal of STEM Education: Innovations and Research, 14(1), 12-19. Retrieved from http://jstem.org/index.php/JSTEM/article/view/1665

Rojewski, J. W., Asunda, P., \& Kim, S. J. (2009). Trends in career and technical education research. Journal of Career and Technical Education, 24(2), 5768. doi:10.21061/jcte.v24i2.457

Rose, M. A., Shumway, S., Carter, V., \& Brown, J. (2015). Identifying characteristics of technology and engineering teachers striving for excellence using a modified Delphi. Journal of Technology Education, 26(2), 2-21. doi:10.21061/jte.v26i2.a.1

Smith-Hughes National Vocational Education Act of 1917, Pub. L. No. 64-347, Ch. 114, 39 Stat. 929 (1917).

Snyder, J. F., \& Hales, J. A. (1981). Jackson's Mill industrial arts curriculum theory. Charleston, WV: West Virginia Department of Education.

Strimel, G., \& Grubbs, M. E. (2016). Positioning technology and engineering education as a key force in STEM education. Journal of Technology Education, 27(2), 21-36. doi:10.21061/jte.v27i2.a.2

Tobin, K., \& Tippins, D. (1993). Constructivism as a referent for teaching and learning. In K. Tobin (Ed.), The practice of constructivism in science education (pp. 3-21). Hillsdale, NJ: Erlbaum.

Titscher, S., Meyer, M., Wodak, R., \& Vetter, E. (2000). Methods of text and discourse analysis. Thousand Oaks, CA: Sage.

Urias, D., Gallagher, P., \& Wartman, J. (2012). Critical features and value in assessing a research experience for undergraduates: The case of Engineering Cities. Journal of STEM Education, 13(1), 30-42. Retrieved from https://jstem.org/index.php/JSTEM/article/view/1517

von Glasersfeld, E. (1989). Constructivism in education. In T. Husen \& T. N. Postlethwaite (Eds.), The international encyclopedia of education (Supplementary Vol. 1, pp. 182-183). Oxford, England: Pergamon Press. 
Walther, J., Kellam, N., Sochacka, N., \& Radcliffe, D. (2011). Engineering competence? An interpretive investigation of engineering students' professional formation. Journal of Engineering Education, 100(4), 703740. doi:10.1002/j.2168-9830.2011.tb00033.x

White, C., Wood, K., \& Jensen, D. (2012). From brainstorming to C-Sketch to principles of historical innovators: Ideation techniques to enhance student creativity. Journal of STEM Education, 13(5), 12-25. Retrieved from https://jstem.org/index.php/JSTEM/article/view/1621

Wicklein, R. C. (2006). Five good reasons for engineering design as the focus for technology education. The Technology Teacher, 65(7), 25-29.

Wilhelmsen, C. A., \& Dixon, R. A. (2016). Identifying indicators related to constructs for engineering design outcome. Journal of Technology Education, 27(2), 57-77. doi:10.21061/jte.v27i2.a.4

\section{About the Authors}

Paul A. Asunda (pasunda@ @ purdue.edu) is an Assistant Professor in the Department of Technology Leadership and Innovation at Purdue University.

Jenny Quintana (quintan3@purdue.edu) is a graduate student in the Department of Technology Leadership and Innovation at Purdue University. 